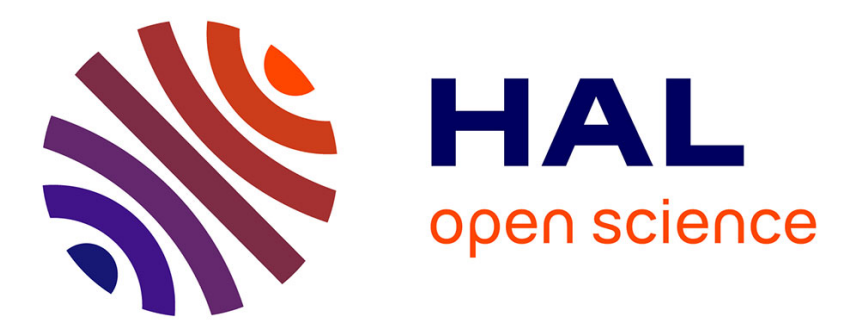

\title{
A year of lava fountaining at Etna: Volumes from SEVIRI
}

G. Ganci, Andrew J.L. J.L. Harris, C. del Negro, Yannick Guéhenneux, A. Cappello, Philippe Labazuy, S. Calvari, Mathieu Gouhier

\section{- To cite this version:}

G. Ganci, Andrew J.L. J.L. Harris, C. del Negro, Yannick Guéhenneux, A. Cappello, et al.. A year of lava fountaining at Etna: Volumes from SEVIRI. Geophysical Research Letters, 2012, 39, pp.L06305. 10.1029/2012GL051026 . hal-00793981

\section{HAL Id: hal-00793981 \\ https://hal.science/hal-00793981}

Submitted on 29 Nov 2021

HAL is a multi-disciplinary open access archive for the deposit and dissemination of scientific research documents, whether they are published or not. The documents may come from teaching and research institutions in France or abroad, or from public or private research centers.
L'archive ouverte pluridisciplinaire HAL, est destinée au dépôt et à la diffusion de documents scientifiques de niveau recherche, publiés ou non, émanant des établissements d'enseignement et de recherche français ou étrangers, des laboratoires publics ou privés.

$$
\text { Copyright }
$$




\title{
A year of lava fountaining at Etna: Volumes from SEVIRI
}

\author{
G. Ganci, ${ }^{1}$ A. J. L. Harris, ${ }^{2}$ C. Del Negro, ${ }^{1}$ Y. Guehenneux, ${ }^{2}$ A. Cappello, ${ }^{1,3}$ P. Labazuy, ${ }^{2}$ \\ S. Calvari, ${ }^{1}$ and M. Gouhier ${ }^{2}$ \\ Received 23 January 2012; revised 28 February 2012; accepted 29 February 2012; published 28 March 2012.
}

[1] We present a new method that uses cooling curves, apparent in high temporal resolution thermal data acquired by geostationary sensors, to estimate erupted volumes and mean output rates during short lava fountaining events. The 15 minute temporal resolution of the data allows phases of waxing and peak activity to be identified during short (150-to810 minute-long) events. Cooling curves, which decay over 8-to-21 hour-periods following the fountaining event, can also be identified. Application to 19 fountaining events recorded at Etna by MSG's SEVIRI sensor between 10 January 2011 and 9 January 2012, yields a total erupted dense rock lava volume of $\sim 28 \times 10^{6} \mathrm{~m}^{3}$, with a maximum intensity of $227 \mathrm{~m}^{3} \mathrm{~s}^{-1}$ being obtained for the 12 August 2011 event. The timeaveraged output over the year was $0.9 \mathrm{~m}^{3} \mathrm{~s}^{-1}$, this being the same as the rate that has characterized Etna's effusive activity for the last 40 years. Citation: Ganci, G., A. J. L. Harris, C. Del Negro, Y. Guehenneux, A. Cappello, P. Labazuy, S. Calvari, and M. Gouhier (2012), A year of lava fountaining at Etna: Volumes from SEVIRI, Geophys. Res. Lett., 39, L06305, doi:10.1029/ 2012 GL051026.

\section{Introduction}

[2] The 11-13 January 2011 lava fountain event of Mt. Etna volcano (Sicily, Italy) heralded a new period of activity characterized by frequent fountaining events of short duration and high intensity, with a further 18 events occurring through 5 January 2012 (Table 1). A prolonged period of activity marked by frequent fountaining events also occurred between 1996 and 2001, during which time 105 events erupted a dense-rock-equivalent (DRE) volume of $\sim 90 \times 10^{6} \mathrm{~m}^{3}$ [Behncke et al., 2006]. Both activity periods can be placed within a longer term phase of increased output that began in 1971 [Wadge and Guest, 1981; Behncke and Neri, 2003; Smethurst et al., 2009; Harris et al., 2011].

[3] In tracking, documenting and comparing lava fountain events, two parameters are key: event magnitude, i.e., volume in $\mathrm{kg}$ or $\mathrm{m}^{3}$, and intensity, i.e., mean output rate (MOR) in $\mathrm{kg} \mathrm{s}^{-1}$ or $\mathrm{m}^{3} \mathrm{~s}^{-1}$. The recent availability of mid- and thermal-infrared data at a frequency of 15 minutes from geostationary platforms, such as GOES, MTSAT and Meteosat Second Generation, have allowed the construction of lava discharge rate time series during such short-lived fountain-fed effusive events [Bonaccorso et al., 2011a;

\footnotetext{
${ }^{1}$ Istituto Nazionale di Geofisica e Vulcanologia, Catania, Italy.

${ }^{2}$ Laboratoire Magmas et Volcans, Université Blaise Pascal, Clermont Ferrand, France.

${ }^{3}$ Dipartimento di Informatica e Matematica, Università di Catania, Catania, Italy.

Copyright 2012 by the American Geophysical Union. 0094-8276/12/2012GL051026
}

Calvari et al., 2011; Gouhier et al., 2012; Vicari et al., 2011]. The same time-series can be used to yield volume and intensity, with the continuous presence of the satellite sensor in a fixed-position geostationary orbit meaning that data are always available for the targeted location. As a result two methodologies have been applied to extract time averaged discharge rates (TADR) and volumes from geostationary satellite data. The first, as applied to SEVIRI data for Etna's 11-13 January 2011 event by Vicari et al. [2011], used the spectral-radiance-to-TADR conversion of Harris et al. [1997] to obtain event intensity and volume, a method that boils down to an empirical conversion between active lava area and TADR [Wright et al., 2001; Harris et al., 2007a; Harris and Baloga, 2009]. The second was also applied to SEVIRI data for Etna's 11-13 January 2011 event by Gouhier et al. [2012] and used the approach of Yokoyama [1957] to convert the total heat liberated by the lava during cooling ( $\mathrm{E}$, in Joules) to the mass or volume of lava required to generate that quantity of heat. Written in terms of mass $(\mathrm{M}$ in $\mathrm{kg})$, this relation is:

$$
M=\frac{E}{c_{p} \Delta T+L \Delta \phi}
$$

in which $c_{p}$ is lava heat capacity, $\Delta \mathrm{T}$ is total cooling from eruption temperature to ambient, $\mathrm{L}$ is latent heat of crystallization and $\Delta \phi$ is the total crystallization in cooling through $\Delta \mathrm{T}$.

[4] The problem with the first approach is that the hot spot is often partially or completely obscured by the tephra plume ascending above the fountain during the event and/or is saturated. This means that TADRs cannot always be calculated during the peak fountaining phase (see Table 1). The problem with the second approach is that the hot spot cannot be tracked through total cooling, so that the time integration of heat fluxes ( $\Phi$ in $\mathrm{J} \mathrm{s}^{-1}$ ) required to generate $\mathrm{E}$ is incomplete. Consequently the volume is either underestimated [e.g., Rowland et al., 2003] or $\Delta \mathrm{T}$ has to be adjusted until M output by equation (1) agrees with an independent measure of mass [e.g., Gouhier et al., 2012], that is we reduce to a best fitting function between $\mathrm{E}$ and $\mathrm{M}$. We here present a new method to yield event magnitude and intensity for the effusive portion of the erupted material; a method that utilizes the plume and saturation-free cooling curve and avoids the $\Delta \mathrm{T}$ assumption. We use this method to catalogue the 19 fire fountaining events at Etna spanning the 12 month period beginning 10 January 2011.

\section{The SEVIRI Data Set and Waveform Associated With Lava Fountaining Events}

[5] The Spinning Enhanced Visible and Infrared Imager (SEVIRI) has been flown on the Meteosat Second Generation 
Table 1. Lava Fountains Occurring at Etna Between 10 January 2011 and 9 January 2012

\begin{tabular}{|c|c|c|c|c|}
\hline Lava Fountains & Detected by SEVIRI & Weather Conditions & Ash Interference & Cooling Curve \\
\hline January $12-13,2011$ & YES & Clear Sky & During Fountaining & YES \\
\hline February 18, 2011 & NO & Covered & No info & NO \\
\hline April 10, 2011 & YES & Clear Sky & During \& after Fountaining & YES \\
\hline May $11-12,2011$ & YES & Clear Sky & During Fountaining & YES \\
\hline July 9, 2011 & YES & Clear Sky & During Fountaining & YES \\
\hline July 18-19, 2011 & YES & Clear Sky & Minor & YES \\
\hline July $24-25,2011$ & YES & Cloudy & Minor & YES \\
\hline July 30-31, 2011 & YES & Partly Cloudy & Minor & YES \\
\hline August 5-6, 2011 & YES & Clear Sky & Minor & YES \\
\hline August 12, 2011 & YES & Clear Sky & Minor & YES \\
\hline August 20, 2011 & YES & Slightly Cloudy & During \& after Fountaining & YES \\
\hline August 29, 2011 & YES & Slightly Cloudy & During Fountaining & YES \\
\hline September 8, 2011 & YES & Slightly Cloudy & During Fountaining & YES \\
\hline September 19, 2011 & PARTIALLY & Almost Covered & No info & NO \\
\hline September 28-29, 2011 & YES & Cloudy & Minor & YES \\
\hline October 8, 2011 & YES & Cloudy & Minor & YES \\
\hline October 23-24, 2011 & YES & Almost Clear Sky & Minor & YES \\
\hline November 15, 2011 & YES & Slightly Cloudy & Minor & YES \\
\hline January 5, 2012 & YES & Slightly Cloudy & During Fountaining & YES \\
\hline
\end{tabular}

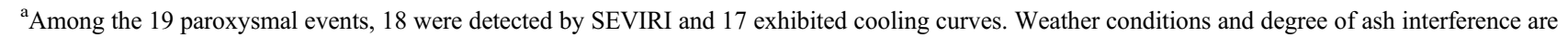
also reported.

satellite since its launch in August 2002. It records data in twelve wavebands, including one in the mid-infrared (band IR3.9, 3.48-4.36 $\mu \mathrm{m}$ ) and two in the thermal infrared (band IR12.0, 11.00-13.00, and band IR13.4, 12.40-14.40 $\mu \mathrm{m}$ ). These two bands have been shown particularly useful in detecting and tracking hot spots associated with effusive activity [Hirn et al., 2008; Bonaccorso et al., 2011b; Ganci et al., 2011, 2012], and provide data every 15 minutes at a spatial resolution of $3 \mathrm{~km}$. The SEVIRI record for Etna's lava fountaining events of 2011, plus the first event of 2012, is summarized in Table 1 . We see that 18 of the 19 events were detected, although 10 were likely cloud contaminated. The typical waveform retrieved is given in Figure 1, and shows three phases. The first phase involves a short period of increasing heat fluxes, but during which low and unsaturated spectral radiances are recorded in IR3.9. The second phase is marked by a rapid increase to high heat fluxes. This phase marks the main fountaining activity during which the hot spot can be either saturated or obscured by the cold plume, so that the peak phase can be marked by a trough in the heat flux time series, and/or scattered behavior, in the case of plume contamination. The third phase is characterized by waning heat flux, marked by a well formed cooling curve, during which time the lava flows emplaced by the fountaining stagnate and cool. Waveforms for all fountainfed lava flows recorded by SEVIRI during 2011 are given in the auxiliary material and show the same generic form. ${ }^{1}$

\section{Methodology}

[6] Because of saturation and plume obscuration problems during the fountaining events, we use the cooling curve to estimate lava volume. To do this, we take the measured cooling curve and fit this to a theoretical cooling curve. Best fit is achieved by adjusting the area of cooling lava until the measured and theoretical curves match. To achieve this we complete the following steps. First, we assume a thermally homogenous lava flow field at the pixel scale and estimate the

${ }^{1}$ Auxiliary materials are available in the HTML. doi:10.1029/ 2012GL051026. surface temperature $\left(\mathrm{T}_{\text {surf }}\right)$ for a stagnant, stable, cooling lava surface as a function of time ( $t$ ) following solution of the Stefan cooling problem [Hon et al., 1994; Harris et al., 2007b, 2008],

$$
\begin{aligned}
t= & \left\{\left[\left(\frac{T_{h}-T_{a}}{\varepsilon \sigma\left(T_{\text {surf }}{ }^{4}-T_{a}^{4}\right)+h_{c}\left(T_{\text {surf }}-T_{a}\right)}-\frac{R_{c} R_{r}}{R_{c}+R_{r}}\right) k\right]\right. \\
& \left.\cdot 1000 \frac{1}{2 \lambda}\right\}^{2} \frac{1}{\kappa}
\end{aligned}
$$

in which $T_{h}$ is the starting temperature, $T_{a}$ is the ambient temperature, $\varepsilon$ is emissivity, $\sigma$ is the Stefan-Boltzmann constant, $h_{c}$ is the convective heat transfer coefficient, $\mathrm{k}$ is thermal conductivity, $\lambda$ is a dimensionless scaling value and $\kappa$ is thermal diffusivity. $R_{c}$ and $R_{r}$ are the thermal resistance terms for convection and radiation, respectively

$$
R_{c}=\frac{1}{h_{c}}, R_{r}=\frac{T_{h}-T_{a}}{\varepsilon \sigma\left(T_{h}^{4}-T_{a}^{4}\right)}
$$

To apply this relation at Etna we use $\mathrm{T}_{\mathrm{h}}=1000^{\circ} \mathrm{C}, \mathrm{T}_{\mathrm{a}}=25^{\circ} \mathrm{C}$, $\varepsilon=0.98, \mathrm{~h}_{\mathrm{c}}=50 \mathrm{~W} \mathrm{~m}^{-2} \mathrm{~K}^{-1}, \mathrm{k}=1 \mathrm{~W} \mathrm{~m}^{-1} \mathrm{~K}^{-1}$ and $\kappa=5 \times 10^{-7} \mathrm{~m}^{2} \mathrm{~s}^{-1}$, with $\lambda$ of 0.421 as given by Turcotte and Schubert [2002] for basalt. Next, we convert the temperature obtained at each time step to a radiative heat flux density ( $Q$ in $\mathrm{W} \mathrm{m}^{-2}$ ), which we convert to a radiative heat flux ( $\Phi$ in W) by multiplying by the area of cooling lava $\left(\mathrm{A}_{\text {lava }}\right.$ in $\left.\mathrm{m}^{2}\right)$. We then consider two end member area conditions. For condition 1 lava area is obtained from the volume divided by a minimum expected thickness. For condition 2 lava area is obtained from the volume divided by a maximum expected thickness. Best fit is determined by minimizing the mean squared error between the modeled radiative heat fluxes and the measured heat flux curve. This is achieved by applying the Nelder-Mead algorithm. The quality of the fit is quantified using $\mathrm{R}^{2}$ with a value of one indicating a perfect fit (zero being no fit). Fit results are given in Table 2. In achieving these fits, we use an assumed lava flow thickness set from field measurements for lava flow units emplaced during lava fountains at Mt Etna [see Harris and Neri, 2002; Calvari et al., 2011; Vicari et al., 2011]. These studies indicate that a thickness of between $1 \mathrm{~m}$ and $2 \mathrm{~m}$ 


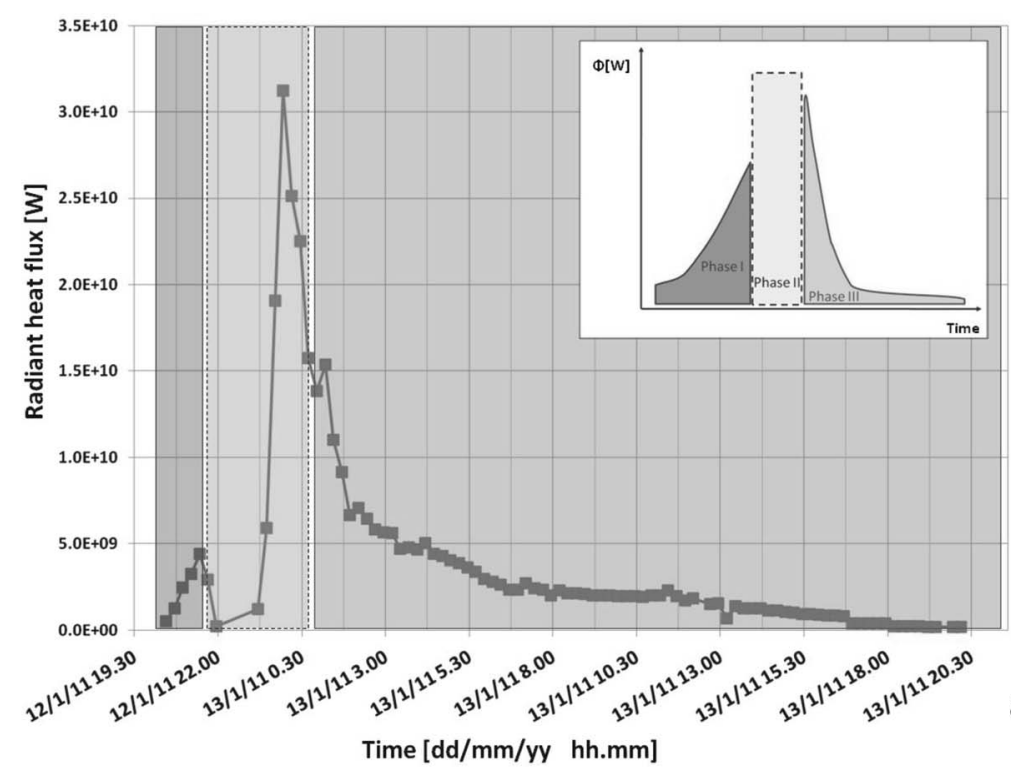

a)

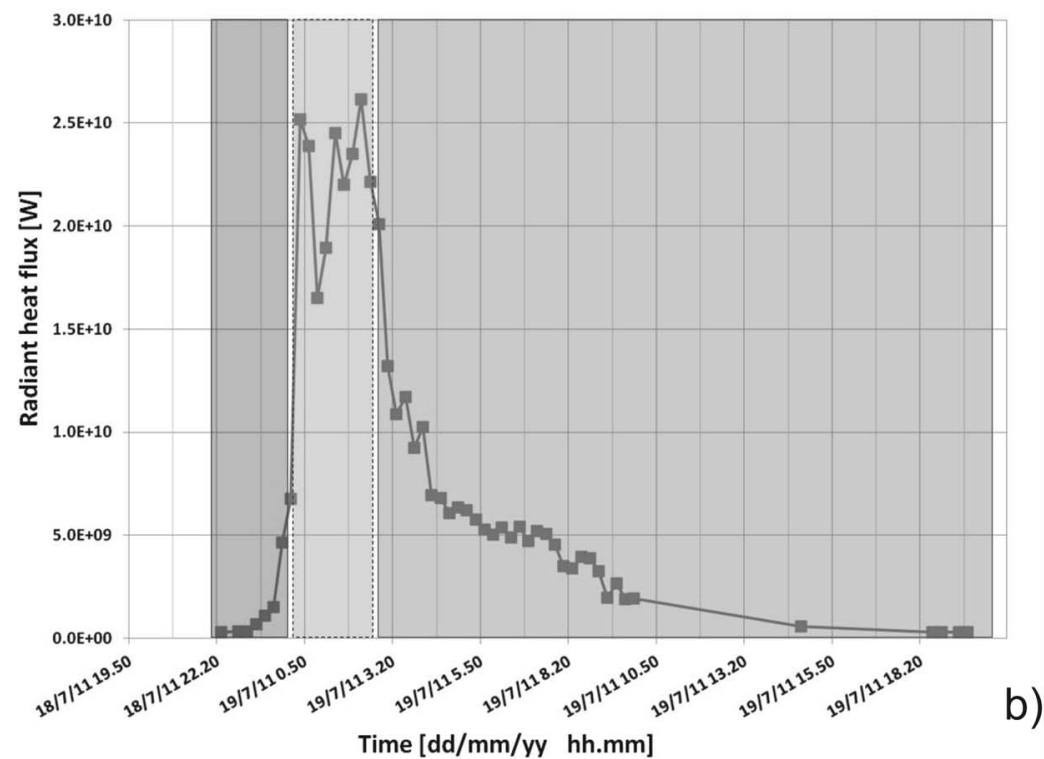

Figure 1. SEVIRI-derived radiant heat flux computed during the (a) 12-13 January 2011 and (b) 18-19 July 2011 Etna lava fountains. The grey bars identify the three phases that characterize these fountaining events, with the generic waveform being given in the inset.

is appropriate. For example, best fit for the 12-13 January data set of Figure $2 \mathrm{a}$ is obtained using a volume of $1.55 \times 10^{6} \mathrm{~m}^{3}$ divided by a thickness of $1 \mathrm{~m}$ to give a maximum bound for the lava area of $1.55 \times 10^{6} \mathrm{~m}^{2}$. This generates curve 1 . Dividing the same volume by $2 \mathrm{~m}$ gives a minimum bound for the lava area of $0.77 \times 10^{6} \mathrm{~m}^{2}$ and generates curve 2 . The two curves provide a best-fit to the SEVIRI-derived cooling curve, and compare with a field-data-derived DRE lava volume of 0.83 $1.77 \times 10^{6} \mathrm{~m}^{3}$ and a lava flow field area of $1.07 \times 10^{6} \mathrm{~m}^{2}$ [Calvari et al., 2011].

[7] When applied to all other data sets, the same thickness conditions provided the best-fit with the SEVIRI-derived cooling curves. By way of example, the fit for the 19 July event is given in Figure $2 \mathrm{~b} . \mathrm{R}^{2}$ values were computed as 1-SSR/SST, where SSR is the sum of squared residuals (differences between observed and modeled values) and SST is the sum of squared deviations (differences between observed values and their average). Fitting results show $\mathrm{R}^{2}$ values greater than 0.60 for 15 events, and greater than 0.80 for 8 events. The worst fits are found for the events of 24-25 July and 8 October $2011\left(\mathrm{R}^{2}\right.$ of 0.59 and 0.49 , respectively). Both events experienced the most cloudy conditions.

\section{Results}

[8] We were able to identify well-defined cooling curves following 17 of the 19 events, as identified in Table 1. Of these, three events were affected by cloud cover, and two by ash that lingered during the onset of cooling to possibly reduce the radiative heat flux estimations at certain points during the cooling process. We note, though, that we fit the general shape of the cooling curve, so that weather conditions and ash will only impact our results if full cloud (or ash) cover occurs during the entire duration of cooling phase meaning that the shape 
Table 2. Lava Fountain Durations, Volumes and MORs as Retrieved From SEVIRI Data ${ }^{a}$

\begin{tabular}{|c|c|c|c|c|c|}
\hline Date & $\begin{array}{l}\text { Duration [minutes] } \\
\text { (Phases } 1 \& 2 \text { ) }\end{array}$ & $\begin{array}{l}\text { Duration [hours] } \\
\quad \text { (Phase 3) }\end{array}$ & Volume $\left[\mathrm{m}^{3}\right]$ & $\begin{array}{l}\text { Mean Output Rate } \\
\text { (MOR) }\left[\mathrm{m}^{3} / \mathrm{s}\right]\end{array}$ & $\mathrm{R}^{2}$ \\
\hline January $12-13,2011$ & 255 & 19.50 & 1550000 & 101.2 & 0.87 \\
\hline February 18, 2011 & N/A & N/A & N/A & N/A & $\mathbf{N} / \mathbf{A}$ \\
\hline April 10, 2011 & 495 & 12.70 & 877000 & 29.5 & 0.81 \\
\hline May 11-12, 2011 & 570 & 14.25 & 1474000 & 43.1 & 0.69 \\
\hline July 9, 2011 & 243 & 14.45 & 1492000 & 102.3 & 0.74 \\
\hline July 18-19, 2011 & 240 & 17.25 & 2139000 & 148.5 & 0.92 \\
\hline July 24-25, 2011 & 630 & 8.00 & 988000 & 26.1 & 0.59 \\
\hline July 30-31, 2011 & 810 & 10.50 & 2223000 & 45.7 & 0.83 \\
\hline August 5-6, 2011 & 270 & 9.50 & 1588000 & 98.0 & 0.77 \\
\hline August 12, 2011 & 210 & 14.25 & 2857000 & 226.7 & 0.82 \\
\hline August 20, 2011 & 330 & 20.75 & 1401000 & 70.8 & 0.70 \\
\hline August 29, 2011 & 255 & 14.00 & 1739000 & 113.7 & 0.90 \\
\hline September 8, 2011 & 180 & 13.25 & 1216000 & 112.6 & 0.82 \\
\hline September 19, 2011 & N/A & N/A & N/A & N/A & N/A \\
\hline September 28-29, 2011 & 228 & 7.45 & 406000 & 29.7 & 0.65 \\
\hline October 8, 2011 & 465 & 8.25 & 843000 & 30.2 & 0.49 \\
\hline October 23-24, 2011 & 150 & 11.75 & 1311000 & 145.7 & 0.70 \\
\hline November 15, 2011 & 273 & 9.70 & 1809000 & 110.4 & 0.91 \\
\hline January 5, 2012 & 318 & 11.00 & 1494000 & 78.3 & 0.73 \\
\hline
\end{tabular}

${ }^{\mathrm{a}}$ Also given are the $\mathrm{R}^{2}$ best fits between the modelled and recorded cooling curves. Bolded data highlight events affected by ash interference after fountaining and cloudy conditions (see Table 1).
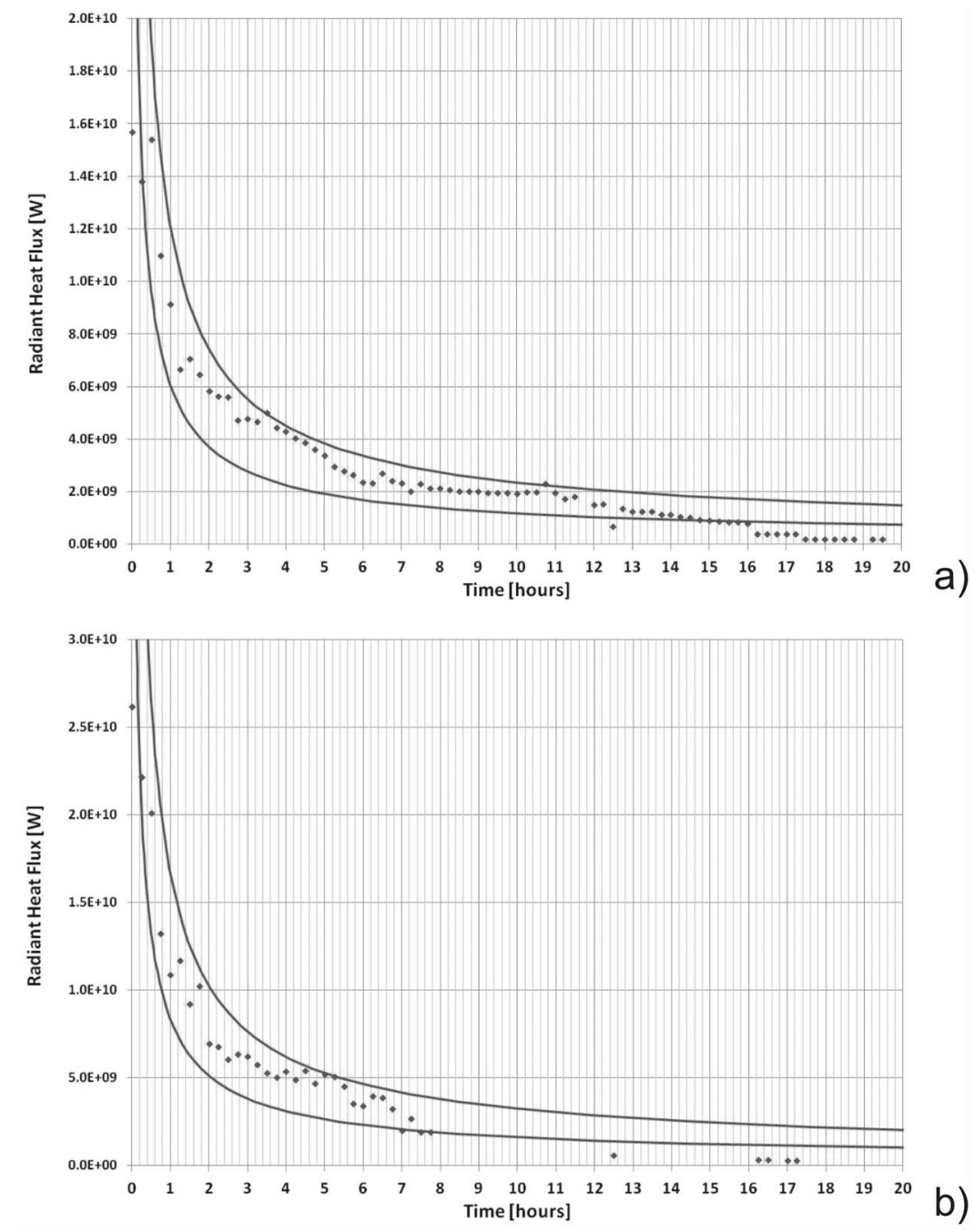

Figure 2. Actual cooling curve (dots) and minimum and maximum bounds for the theoretical cooling curve (lines) following: (a) 12-13 January 2011 and (b) 18-19 July 2011 lava fountains. 


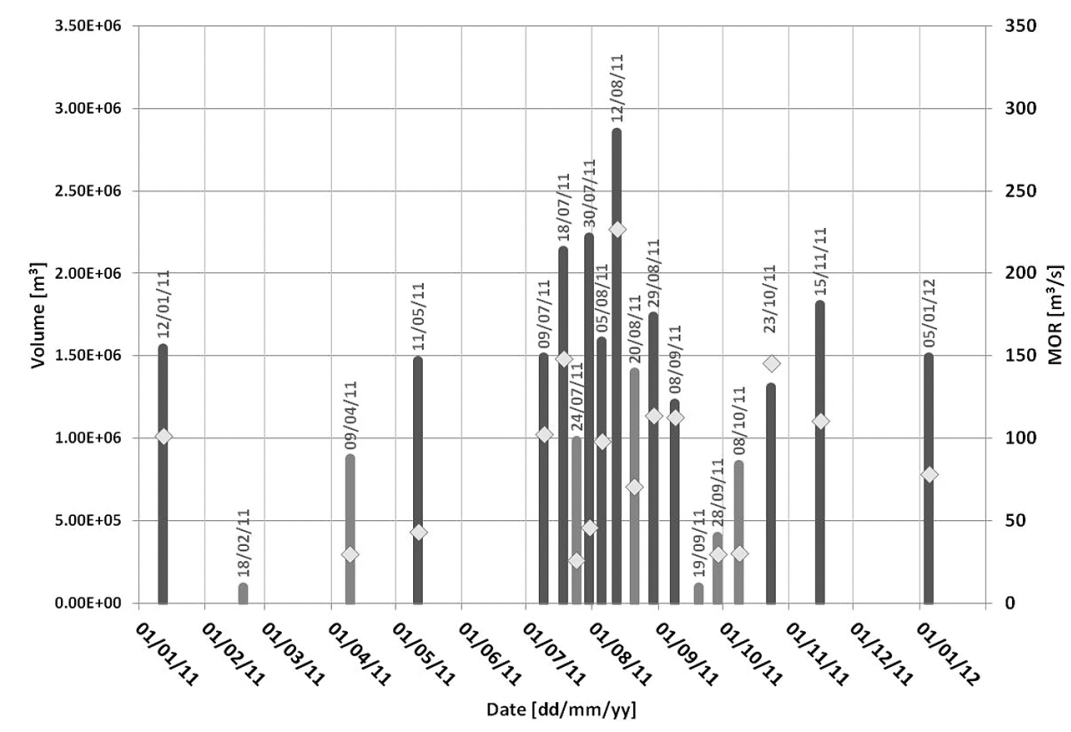

Figure 3. Volumes (histogram bars) and mean output rate (MOR, diamonds) obtained from the SEVIRI-derived cooling curves for Etna's lava fountains between 10 January 2011 and 9 January 2012. Pale grey bars show the volumes associated with cloud contaminated events (see Table 1).

of the curve cannot be defined. All fits between SEVIRIderived and theoretical cooling curves are given in auxiliary material and were obtained using the typical flow field thickness assumption of $1-2 \mathrm{~m}$, this being based upon the typical thickness range from field-based measurements of fountain-fed flows on Etna by Harris and Neri [2002] and Calvari et al. [2011]. Lava flow volumes obtained in this way are given in Table 2 and reveal erupted lava volumes varying between a minimum volume of $0.4 \times 10^{6} \mathrm{~m}^{3}$ (erupted on 28 September) and a maximum of $2.85 \times 10^{6} \mathrm{~m}^{3}$ (erupted on 12 August). The mean and standard deviation is $1.3 \times 10^{6} \mathrm{~m}^{3}$ and $0.7 \times 10^{6} \mathrm{~m}^{3}$, for a total volume of $25.4 \times 10^{6} \mathrm{~m}^{3}$ erupted during 17 events. This total may be as high as $\sim 28 \times 10^{6} \mathrm{~m}^{3}$ over 19 events if we assume that the two missing events had average volumes.

[9] Mean output rate (MOR) was obtained by dividing the volume by event duration as detected by SEVIRI (i.e., the duration of phases 1 and 2 in Figure 1). These durations and MORs are also given in Table 2. We see that event intensities varied between 26 and $227 \mathrm{~m}^{3} \mathrm{~s}^{-1}$, with an average and standard deviation of 89 and $54 \mathrm{~m}^{3} \mathrm{~s}^{-1}$. This compares with intensities of between 15 and $205 \mathrm{~m}^{3} \mathrm{~s}^{-1}$ estimated for Etna's 1996 to 2001 fountaining events [Behncke et al., 2006] and $183 \mathrm{~m}^{3} \mathrm{~s}^{-1}$ for fountains associated with Etna's 1989 eruption [Bertagnini et al., 1990]. On a global scale, we can also compare our Etna values with rates of between 9 and $308 \mathrm{~m}^{3} \mathrm{~s}^{-1}$ estimated for 13 fountaining events at Pu'u 'O'o (Kilauea) during 1983-1984 [Wolfe et al., 1987], and of up to $340 \mathrm{~m}^{3} \mathrm{~s}^{-1}$ obtained for the 16th fountaining event of Kilauea Iki's 1959 eruption [Richter et al., 1970].

[10] The variation in magnitude and intensity of each event with time is plotted in Figure 3. We see that the events increased in magnitude and intensity through July 2011, with the 12 August 2011 event having the highest magnitude and intensity. Thereafter magnitude and intensity declined, the events of October 2011-January 2012 having similar magnitudes and intensities to those recorded between January and May 2011. We also see an increase in event frequency during the July-September magnitude and intensity peak, during which time 12 of the 19 events occurred.

\section{Discussion}

[11] The twelve months spanning 10 January 2011 to 9 January 2012 were characterized by fountaining at Etna during which time $\sim 28 \times 10^{6} \mathrm{~m}^{3}$ of lava was erupted during 19 events. This compares with $\sim 72 \times 10^{6} \mathrm{~m}^{3}$ of lava erupted during 105 events between 1996 and 2001 [Behncke et al., 2006]. It seems that the current output is thus more than twice as high as during the 1996 to 2001 fountaining events (if we multiply our average volume by 105 we arrive at a total volume of $\sim 154 \times 10^{6} \mathrm{~m}^{3}$ ). The current fountaining events are also set within the context of a high output rate phase at Etna which began in 1971 [Wadge and Guest, 1981; Behncke and Neri, 2003; Smethurst et al., 2009], and since which time lava discharge has continued at a time-averaged rate of $0.8 \mathrm{~m}^{3} \mathrm{~s}^{-1}$ [Harris et al., 2011]. This had increased from 0.2 $0.4 \mathrm{~m}^{3} \mathrm{~s}^{-1}$ for the period 1759 to 1970 [Wadge et al., 1975; Wadge and Guest, 1981]. Over our twelve month period we have a time-averaged output of $0.9 \mathrm{~m}^{3} \mathrm{~s}^{-1}$, consistent with continuation of this high output rate trend. Our 12-month average is also identical to the time-averaged rate for the preceding decade (2000-2010) [see Harris et al., 2011, Table 5]. It seems that Etna is beginning the second decade of the 21st century by continuing the high output rate levels that characterized the previous four decades, with partitioning of this output being between many short, but high intensity, events during 2011.

\section{Conclusions}

[12] High temporal resolution infrared data collected by SEVIRI-type sensors on geostationary platforms allow high intensity, but short duration and transient, volcanic events to be tracked, including lava fountain events. The methodology presented here allows the magnitude and intensity of such events (in terms of effused volume and volume flux) to be 
quickly and easily extracted, providing, in this case, an inventory for 17 lava fountain events over 12 months. The model relies on all lava flows stagnating at roughly the same time, so that they also begin to cool at the same time. This means that an average, pixel-wide, radiance can be assumed during the cooling dominated phase. This is then used to describe the flow-field-wide cooling rate (as witnessed by the SEVIRI-derived cooling curve). We thus note that our model is only appropriate for such short-lived effusive events with well defined and relatively uncomplicated cooling curves.

[13] Given the increasing use of direct reception data to contribute to operational monitoring and hazard assessment [e.g., Vicari et al., 2009, 2011; Herault et al., 2009], such a capability adds to our ability to track and document such short, but intense and potentially hazardous events, in a timely fashion. Indeed these routines were developed and tested for operational use with our two SEVIRI-driven hot spot detection and monitoring tools: HOTSAT [Ganci et al., 2011, 2012] and HOTVOLC [Labazuy et al., 2012], and can potentially be applied to any volcanic deposit (effusive or explosive) exhibiting a cooling curve within the MSG, GOES or MTSAT footprints.

[14] Acknowledgments. We are grateful to EUMETSAT for SEVIRI data. We thank Matthew Patrick and an anonymous reviewer for constructive and supportive comments that helped clarify the operation of this methodology, and AE Ruth Harris for her efficient handling.

[15] The Editor thanks Matthew Patrick and Matthew Blackett for their assistance in evaluating this paper.

\section{References}

Behncke, B., and M. Neri (2003), Cycles and trends in the recent eruptive behaviour of Mount Etna (Italy), Can. J. Earth Sci., 40, 1405-1411, doi:10.1139/e03-052.

Behncke, B., M. Neri, E. Pecora, and V. Zanon (2006), The exceptional activity and growth of the Southeast Crater, Mount Etna (Italy) between 1996 and 2001, Bull. Volcanol., 69, 149-173, doi:10.1007/s00445-0060061-x.

Bertagnini, A., S. Calvari, M. Coltelli, P. Landi, M. Pompilio, and V. Scribano (1990), The 1989 eruptive sequence, in Mt. Etna: The 1989 Eruption, edited by F. Barberi, A. Bertagnini, and P. Landi, pp. 10-22, Giardini, Pisa, Italy.

Bonaccorso, A., A. Bonforte, S. Calvari, C. Del Negro, G. Di Grazia, G. Ganci, M. Neri, A. Vicari, and E. Boschi (2011a), The initial phases of the 20082009 Mount Etna eruption: A multidisciplinary approach for hazard assessment, J. Geophys. Res., 116, B03203, doi:10.1029/2010JB007906.

Bonaccorso, A., et al. (2011b), Dynamics of a lava fountain revealed by geophysical, geochemical and thermal satellite measurements: The case of the 10 April $2011 \mathrm{Mt}$ Etna eruption, Geophys. Res. Lett., 38, L24307, doi:10.1029/2011GL049637.

Calvari, S., G. Salerno, L. Spampinato, M. Gouhier, A. La Spina, E. Pecora, A. J. L. Harris, P. Labazuy, E. Biale, and E. Boschi (2011), An unloading foam model to constrain Etna's 11-13 January 2011 lava fountaining episode, J. Geophys. Res., 116, B11207, doi:10.1029/2011JB008407.

Ganci, G., A. Vicari, L. Fortuna, and C. Del Negro (2011), The HOTSAT volcano monitoring system based on a combined use of SEVIRI and MODIS multispectral data, Ann. Geophys., 54(5), 544-550, doi:10.4401/ag-5338.

Ganci, G., A. Vicari, A. Cappello, and C. Del Negro (2012), An emergent strategy for volcano hazard assessment: From thermal satellite monitoring to lava flow modeling, Remote Sens. Environ., 119, 197-207, doi:10.1016/ j.rse.2011.12.021.

Gouhier, M., A. Harris, S. Calvari, P. Labazuy, Y. Guéhenneux, F. Donnadieu, and S. Valade (2012), Lava discharge during Etna's January 2011 fire fountain tracked using MSG-SEVIRI, Bull. Volcanol., doi:10.1007/s00445-0110572-y, in press.

Harris, A. J. L., and S. M. Baloga (2009), Lava discharge rates from satellite-measured heat flux, Geophys. Res. Lett., 36, L19302, doi:10.1029/ 2009GL039717.

Harris, A. J. L., and M. Neri (2002), Volumetric observations during paroxysmal eruptions at Mount Etna: Pressurized drainage of a shallow chamber or pulsed supply? J. Volcanol. Geotherm. Res., 116, 79-95, doi:10.1016/ S0377-0273(02)00212-3.
Harris, A. J. L., S. Blake, D. A. Rothery, and N. F. Stevens (1997), A chronology of the 1991 to 1993 Etna eruption using AVHRR data: Implications for real time thermal volcano monitoring, J. Geophys. Res., 102 (B4), 7985-8003, doi:10.1029/96JB03388.

Harris, A. J. L., J. Dehn, and S. Calvari (2007a), Lava effusion rate definition and measurement: A review, Bull. Volcanol., 70, 1-22, doi:10.1007/ s00445-007-0120-y.

Harris, A. J. L., J. Dehn, M. R. James, C. Hamilton, R. Herd, L. Lodato, and A. Steffke (2007b), Pahoehoe cooling, discharge and coverage rates from thermal image chronometry, Geophys. Res. Lett., 34, L19303, doi:10.1029/ 2007GL030791.

Harris, A. J. L., J. Dehn, M. R. James, C. Hamilton, R. Herd, L. Lodato, and A. Steffke (2008), Correction to "Pāhoehoe flow cooling, discharge and coverage rates from thermal image chronometry," Geophys. Res. Lett., 35, L23303, doi:10.1029/2008GL036401.

Harris, A., A. Steffke, S. Calvari, and L. Spampinato (2011), Thirty years of satellite-derived lava discharge rates at Etna: Implications for steady volumetric output, J. Geophys. Res., 116, B08204, doi:10.1029/2011JB008237.

Herault, A., A. Vicari, A. Ciraudo, and C. Del Negro (2009), Forecasting lava flow hazard during the 2006 Etna eruption: Using the magflow cellular automata model, Comput. Geosci., 35(5), 1050-1060, doi:10.1016/ j.cageo.2007.10.008.

Hirn, B., C. Di Bartola, G. Laneve, E. Cadau, and F. Ferrucci (2008), SEVIRI onboard Meteosat Second Generation, and the quantitative monitoring of effusive volcanoes in Europe and Africa, in IEEE International Geoscience and Remote Sensing Symposium (IGARSS 2008), pp. 374377, Inst. of Electr. and Electron. Eng., New York.

Hon, K., J. Kauahikaua, R. Denlinger, and K. Mackay (1994), Emplacement and inflation of pahoehoe sheet flows: Observations and measurements of active lava flows on Kilauea Volcano, Hawaii, Geol. Soc. Am. Bull., 106, 351-370, doi:10.1130/0016-7606(1994)106<0351:EAIOPS >2.3.CO;2.

Labazuy, P., M. Gouhier, A. Harris, Y. Guéhenneux, M. Hervo, J. C. Bergès, P. Cacault, and S. Rivet (2012), Near real-time monitoring of the April-May 2010 Eyjafjallajökull ash cloud: An example of a web-based, satellite-datadriven, reporting system, Int. J. Environ. Pollut., in press.

Richter, D. H., J. P. Eaton, K. J. Murata, W. U. Ault, and H. L. Krivoy (1970), Chronological narrative of the 1959-1960 eruption of Kilauea volcano, U.S. Geol. Surv. Prof. Pap., 537-E, 73 pp.

Rowland, S. K., A. J. L. Harris, M. J. Wooster, F. Amelung, H. Garbeil, L. Wilson, and P. J. Mouginis-Mark (2003), Volumetric characteristics of lava flows from interferometric radar and multispectral satellite data: The 1995 Fernandina and 1998 Cerro Azul eruptions in the western Galapagos, Bull. Volcanol., 65, 311-330, doi:10.1007/s00445-002-0262-x.

Smethurst, L., M. R. James, H. Pinkerton, and J. A. Tawn (2009), A statistical analysis of eruptive activity on Mount Etna, Sicily, Geophys. J. Int., 179(1), 655-666, doi:10.1111/j.1365-246X.2009.04286.x.

Turcotte, D. L., and G. Schubert (2002), Geodynamics, 2nd ed., 456 pp., Cambridge Univ. Press, Cambridge, U. K.

Vicari, A., A. Ciraudo, C. Del Negro, A. Herault, and L. Fortuna (2009), Lava flow simulations using discharge rates from thermal infrared satellite imagery during the 2006 Etna eruption, Nat. Hazards, 50, 539-550, doi:10.1007/s11069-008-9306-7.

Vicari, A., G. Ganci, B. Behncke, A. Cappello, M. Neri, and C. Del Negro (2011), Near-real-time forecasting of lava flow hazards during the 12-13 January 2011 Etna eruption, Geophys. Res. Lett., 38, L13317, doi:10.1029/ 2011GL047545.

Wadge, G., and J. E. Guest (1981), Steady-state magma discharge at Etna 1971-81, Nature, 294, 548-550, doi:10.1038/294548a0.

Wadge, G., G. P. L. Walker, and J. E. Guest (1975), The output of the Etna volcano, Nature, 255, 385-387, doi:10.1038/255385a0.

Wolfe, E. W., M. O. Garcia, D. B. Jackson, R. Y. Koyanagy, C. A. Neal, and A. T. Okamura (1987), The Pu'u'O'o eruption of Kilauea Volcano, episodes 1-20, January 3, 1983, to June 8, 1984, in Volcanism in Hawaii, edited by R. W. Decker, T. L. Wright, and P. H. Stauffer, U.S. Geol. Surv. Prof. Pap., 1350, 471-508.

Wright, R., S. Blake, A. J. L. Harris, and D. A. Rothery (2001), A simple explanation for the space-based calculation of lava eruption rates, Earth Planet. Sci. Lett., 192, 223-233, doi:10.1016/S0012-821X(01)00443-5.

Yokoyama, I. (1957), Energetics in active volcanoes, Bull. Earthquake Res. Inst. Univ. Tokyo, 35, 75-97.

S. Calvari, A. Cappello, C. Del Negro, and G. Ganci, Istituto Nazionale di Geofisica e Vulcanologia, Sezione di Catania, Piazza Roma 2, I-95125 Catania, Italy. (gaetana.ganci@ct.ingv.it)

M. Gouhier, Y. Guehenneux, A. J. L. Harris, and P. Labazuy, Laboratoire Magmas et Volcans, Université Blaise Pascal, 5 Rue Kessler, F-63038 Clermont Ferrand CEDEX, France. 